\title{
Research on Reasonable Tax Avoidance of Small and Medium-sized Enterprises
}

\author{
Mingyue Liu \\ Yantai Nanshan University \\ Longkou, Shandong, China 265713
}

\begin{abstract}
Under the background of market economy, in order to pursue maximization of economic benefit, it has been one of the major events for the small and medium-sized enterprises to reduce their tax burden through reasonable tax avoidance on the premise of not violating the laws and regulations, which may reduce the enterprises' tax burden to a certain extent. In this paper, the analysis is made in terms of reasons and negative effect against the overweight tax burden of Chinese small and medium-sized enterprises, and some suggestions about how to avoid taxes reasonably are proposed.
\end{abstract} $\operatorname{tax}$

Keywords—small and medium-sized enterprises; reasonable

\section{INTRODUCTION}

Small and medium-sized enterprises refer to the economic units having a smaller personnel scale, asset size and operation scale compared with large enterprises. Its definition is different in different countries, different stages of economic development and different industries, and it changes dynamically along with the economic development.

Countries generally define small and medium-sized enterprises from two aspects of quality and quantity. The indexes of quality mainly include the enterprise's organizational form, financing methods and the industrial status, etc., and the indexes of quantity mainly include number of employees, paid-in capital, total assets, etc. Quantity index is more intuitive that that of quality. Most countries take the standard of quantity as the selection of data is easy.

Reasonable tax avoidance refers to the tax payer deals with matters about finance, operation, organization and transaction, and makes financial arrangement and tax planning with the method with lowest tax burden when there are a variety of tax plans within the scope specified by tax law, and on the premise of meeting legislative spirit, to avoid and reduce the tax burden and realize profits maximization and tax minimization without violating tax law. Reasonable tax avoidance refers to the appropriate means that taxpayer adopts avoid tax liability on the premise of respecting tax law and pay taxes by law, to reduce taxation expenditure. One point must be emphasized that reasonable tax avoidance is not tax evasion, but a normal legal activity.

\section{CURRENT SituAtion OF TAXATION OF CHINESE SMALL AND MEDIUM-SIZED ENTERPRISES}

Small and medium-sized enterprises have been an important part of Chinese national economy, playing an important role that cannot be replaced by many large enterprises in social and economic development process. According to statistics, more than 10 million small and medium-sized enterprises have registered in the administration for industry and commerce in China, accounting for more than $99 \%$ of the total registered enterprises, of which their business scope involves almost all the competitive industries, and their total output, sales revenue and total exports volume accounting for $60 \%, 57 \%$ and $60 \%$ respectively of all the total industrial output. However, there are no special tax policies to support small and medium-sized enterprises in China currently.

The reason why small and medium-sized enterprises in our country can develop rapidly before 1994 is the great role of supportive tax policy granted by the state in addition to the opportunity provided by shortage economy. But after the tax reform in 1994, there is no special tax policies to support the development of small and medium-sized enterprises, if any, just the tax preferences scattered in relevant provisions. Overall, currently, the main problems of Chinese tax policies for the small and medium-sized enterprises are: first, the policy objective is not clear, with weak targeted goal. The current tax policy is viewed more as a kind of social policy tools and the methods to solve social problems, but the cultivation of competitive capacity which is very important for small and medium-sized enterprises is neglected, without considering the particularity of small and medium-sized enterprises themselves. Second, the policies are not systemic and normative. Although there are a lot of incentives, they are promulgated in different periods with different background, scattering in some supplementary provisions or notice and various categories of taxes, which is obviously not systemic and normative although the flexibility of tax policy is reflected, and also makes the policy measures lack of effective legal protection, which is not conducive to realize the fair tax bearing and equal competition. Third, the policy is inefficiency due to simple policy means, narrow range, and weak strength. At present, the relevant provisions on tax support for small and medium-sized enterprises in our country is mainly limited to the tax rate and tax exemptions, which cannot adapt to the requirements of different properties and enterprises with different scales, and the practices such as accelerated depreciation and deferred tax 
practice are not common, moreover, the procedure is too strict and trivial. The preference is mainly concentrated at the starting of an enterprise, which is short of the supporting policies in terms of reduce investment risk, raising funds and talent flow guidance. In addition, the current conditions of taxpayers for general VAT exclude many small and medium enterprises. The studies indicate that the abovementioned is obviously not conducive to the development of small and medium-sized enterprises.

At present, there are no special tax policies supporting small and medium-sized enterprises in China. The reason why small and medium-sized enterprises in our country can develop rapidly before 1994 is the great role of supportive tax policy granted by the state in addition to the opportunity provided by shortage economy. But after the tax reform in 1994, there is no special tax policies to support the development of small and medium-sized enterprises, if any, just the tax preferences scattered in relevant provisions. So, the state shall grant strong support to the small and medium-sized enterprises their development in addition to their own management.

Overall, currently, the main problems of Chinese tax policies for the small and medium-sized enterprises are: first, the policy objective is not clear, with weak targeted goal. The current tax policy is viewed more as a kind of social policy tools and the methods to solve social problems, but the cultivation of competitive capacity which is very important for small and medium-sized enterprises is neglected, without considering the particularity of small and medium-sized enterprises themselves. Second, the policies are not systemic and normative. Although there are a lot of incentives, they are promulgated in different periods with different background, scattering in some supplementary provisions or notice and various categories of taxes, which is obviously not systemic and normative although the flexibility of tax policy is reflected, and also makes the policy measures lack of effective legal protection, which is not conducive to realize the fair tax bearing and equal competition. Third, the policy is inefficiency due to simple policy means, narrow range, and weak strength. At present, the relevant provisions on tax support for small and medium-sized enterprises in our country is mainly limited to the tax rate and tax exemptions, which cannot adapt to the requirements of different properties and enterprises with different scales, and the practices such as accelerated depreciation and deferred tax practice are not common, moreover, the procedure is too strict and trivial. The preference is mainly concentrated at the starting of an enterprise, which is short of the supporting policies in terms of reduce investment risk, raising funds and talent flow guidance. In addition, the current conditions of taxpayers for general VAT exclude many small and medium enterprises. The studies indicate that the abovementioned is obviously not conducive to the development of small and medium-sized enterprises.

\section{BASIC Methods FOR REASOnABle TAX AvoIDANCE}

The proverb saying that: "those who are ignorant and confused evade taxes, those who are cunning conduct tax fraud, and the wise ones perform reasonable tax avoidance." Foreign capital enterprises all have their own tax avoidance secret in order to realize the profit maximization and minimization of tax burden. Study the difference between various countries' tax laws and plan the individual or group internal financial tax savings, will be conducive to evade taxes.

There are many commonly used methods of tax avoidance, but commonly they are: take advantage of state preferential tax policies, pricing transfer, cost calculation, financing and leasing.

\section{A. Take Full Use of the Preferential Tax Policies}

The promulgation and implementation of the new tax law takes the power of tax relief back to the state council, avoiding the phenomenon of too much and too chaos of tax reliefs. At the same time, the tax law has regulated various preferential tax policies in the manner of law. Enterprises shall strengthen research on these preferential policies, strive to enjoy the preferential tax policies through income adjusting, to avoid tax to the greatest extent, and expand the enterprise strength. Meanwhile, this can avoid taxes better for high and new technology industry or an encouraged industry, with the main method as below.

- Take advantage of planning directly (for example, enterprises and institutions with less than 300000 yuan annual net income from technology transfer shall be temporarily exempt from tax, just to pay tax for the exceeding portion), affiliate (to affiliate the imported equipment and new products, etc.).

- Critical point planning (individual income tax and small and medium-sized enterprise income tax, for example, making private cars be used publicly).

- Planning of the flow of person (including natural person flow and legal person flow) and utilization of the tax base, tax rate, tax object, tax collection and management, preferential differences, etc. for example, to start small and medium-sized enterprises in the west.

\section{B. Pricing Transfer}

Pricing transfer is one of the basic ways of enterprise to avoid taxes. It refers to the product pricing made by associated enterprises in the process of products exchange and transaction according to their common interests instead of the fair market price in order to share the profits or transfer of profits in economic activity. The transfer price of products using this method may be higher or lower than the market fair price, in order to achieve the purpose of paying less tax or not to pay tax.

The tax avoidance principle of pricing transfer is generally applicable to the associated enterprises with different tax rates. Transfer part of the profits of enterprises with higher tax rate to the enterprises with lower tax rate through pricing transfer, to eventually reduce total tax of the two enterprises.

The method of pricing transfer may be adopted to avoid tax if the tax rates of small and medium-sized enterprises that shall pay tax within a small and medium-sized enterprise group are different, and the profits and losses of small and medium-sized enterprises that shall pay tax within the group are different. The methods are below. 
- Influence the products' costs and profits using the sale price of components and product.

- Make the planning using leasing business.

- Make the planning using intangible assets. (The one which is most difficult to investigate and punish, for example, the royalty)

- Make the planning using machinery and equipment. Push up prices, take shoddy goods as quality goods, and take old one as the new ones (commonly seen in joint venture of small and medium-sized enterprises).

- Use the management costs to allocate and purchase raw materials, etc.

- By way of charging the transportation fee, insurance premium, commissions, etc.

- Influence the products' costs and profits via the purchase price and service life of the fixed assets between associated small and medium-sized enterprises.

- Provide consulting, royalties, loan interest and rent.

\section{Cost-sharing}

Various cost and expenses incurred in the process of enterprise's production and management shall be allocated in the cost as per certain method. Cost-sharing refers to that on the condition the necessary expenses are guaranteed, enterprises strive to find balance in their accounts, to allocate the maximum cost when making allocation, so as to realize tax avoidance to the largest extent.

The commonly used principles of cost-sharing generally include the actual cost allocation, average amortization and irregular amortization, etc. We summarize the general rule if we analyze the depreciation calculation method carefully: no matter what kind of allocation is adopted, as long as costs and expenses are allocated into cost as soon as possible, and make the early cost grater, then the purpose of tax avoidance will be more easily to be achieved to the largest extent.

\section{Avoid Tax through Nominal Financing}

This principle is to use certain financing technology, to enable the enterprise achieve the highest profit level and the lowest tax burden level. Generally speaking, there are three channels of the funds required for production and operation of an enterprise: self accumulation, borrowing and issuing of shares. The bonus of self accumulation is the after-tax profits distributed by the enterprise, while the dividend which shall be paid for shares issuance is also taken as a way of after-tax profit distribution. They cannot offset the income tax payable for current period, so the purpose of tax avoidance cannot be achieved. The loan interest can be deducted from the pre-tax profits and can offset profits, thus to achieve the purpose of tax avoidance eventually.

\section{E. Capital Lease}

Lease refers to a kind of economic behavior that the Lessor to lease assets to the lessee within the time limit stipulated in the deed or contract on the condition of collecting rent. As for the Lessee, the lease may help to avoid the burden of purchasing machinery and equipment, and free from the risk of obsolete equipment. The rent is deducted from pre-tax profits, and it can offset profits, thus the purpose of tax evasion can be achieved.

We are stressing the "legitimacy" of tax avoidance from beginning to end. At present, the operation condition of many small and medium-sized enterprises is not easy. In order to realize their own strong innovation ability and economic vitality, tax avoidance or permission may be a feasible way for the small and medium-sized enterprise.

\section{CASE Analysis of Reasonable TAX AVoidance}

Tax avoidance is not an illegal behavior, and the planning of tax avoidance taxpayers from the perspective of their own economic benefit maximization is objective existence. Then the explanation will be made through the following two cases.

Case 1: A real estate development company developed a five-star restaurant in a coastal city, and sold it to a foreign investor. The development cost is 1.8 billion yuan and selling price is 2.8 billion yuan. Pursuant to regulations, the business tax, urban maintenance and construction tax, education surcharge, stamp tax and land value-added tax shall be paid for this transaction, totally about 177 million yuan (save the calculation process).

Tax avoidance planning: the real estate development company may invest and set up a subsidiary named "XXX Hotel", and transfer all the equity of this Hotel to foreign investors upon fixed assets of this Hotel is completed, then the aforementioned tax may be avoided.

Step one: invest and establish a holding subsidiary named "XXX Hotel" together with other shareholders, and XXX Hotel shall be qualified as a legal person to conduct independent accounting.

Step two: conduct fixed assets construction for XXX Hotel, with relevant construction funds to be provided by the real estate development company, which funds shall be treated as the account payable.

Step three: upon the fixed assets are completed, real estate company transfers all the equity of Hotel to foreign investors and recover the equity transfer price as well as all the creditor's rights of Hotel.

Tax avoidance results: through the aforementioned planning, although enterprise income tax is need to be paid for equity transfer, this part is required to be paid for the real estate development benefits, and there is no need for equity transfer business to pay business tax, urban construction tax, educational surcharges and land value-added tax, thus, the huge tax amount generated in the process of real estate transfer is avoided.

Case 2: in order to conduct promotion, a development company offer customers privilege and give customers renovation costs. There is a senior residence, of which the selling price is 10000 yuan $/ \mathrm{m}^{2}$, covering an area of $100 \mathrm{~m}^{2}$, 
and the price is 1 million yuan. In the contract between developer and customer, 100000 yuan is stipulated to be given to the customer as renovation costs, and the methods about how to avoid tax for the 100000 yuan are listed below.

Tax avoidance planning: in accordance with the provisions, 100000 yuan shall be involved in the propagandist cost, if the cost is in the tax payment range of the enterprise's all sales income, then it can be drawn from the enterprise's pre-tax income in the current year. If the contract stipulates that this residence is a renovated one delivered to the customer, without emphasis on the 100000 yuan of renovation costs, then this 100000 yuan of renovation costs can be included in cost, and is allowed to be deducted pre-tax.

Tax avoidance results: the 100000 yuan of renovation costs become the item which can be deducted pre-tax after such planning, and this renovation costs can be digested easily.

To choose the best tax payment program among various alternative operation types through tax avoidance planning, subjectively, it is for reducing tax burden, but objectively, it is the principle of gradually moving forward the optimized industrial structure and the rational allocated resources with the efforts of state's economic leverage for tax, reflecting the national industrial policy, thus to make the national tax revenue macroeconomic regulation and control function be played better and faster.

\section{PRINCIPLE OF REASONABLE TAX AVOIDANCE OF SMALL AND MEDIUM-SIZED ENTERPRISES}

\section{A. Principle of Legality}

The biggest difference between reasonable tax avoidance and tax evasion lies in that reasonable tax avoidance always complies with the tax law from content to form, without violating provisions of the tax law, which means the whole process of tax avoidance may stand the test of current tax law all the time.

\section{B. Planning Principle}

In the process of tax, generally economic behavior will happen earlier, and the tax liability is in the latter, duty is responsible for the behavior, which provides the precondition for reasonable tax avoidance. Therefore, enterprise arranges tax liability reasonably to reduce the tax burden through the advanced arrangement of various economic activities, and via the release of economic behavior in a planed and orderly way.

\section{Selective Principle}

Reasonable tax avoidance itself needs certain cost, and here the cost not only includes the general manpower, material resources and financial resources costs, but also includes the opportunity cost of not to choose suboptimal solution. If the tax avoidance cost is not considered in tax avoidance scheme, and not conduct the cost-benefit analysis, then the opposite results will certainly be got. So "in the face of a variety of tax plan", scientific selection is still indispensable.

\section{CONCLUSION}

Reasonable tax avoidance benefits to the country and the people. In this paper, the tax avoidance of small and mediumsized enterprises tax avoidance is described, which lies in the understanding of and attitude toward tax avoidance. Although tax avoidance is the loss of national revenue, and it is reluctant for the government, we shall objectively evaluate and treat tax avoidance. As the taxpayers, paying attention to and conduct tax avoidance will bring about direct economic benefits, at the same time, it will be beneficial to the taxpayers to establish legal concept, and maintain the standardization of social and economic order. This is because tax avoidance and tax evasion are two different concepts. Tax avoidance is conducted on the premise of complying with the law without taking advantage of tax law. In fact, it can contribute to the rationalization and improvement of tax system. As for the government, analyze and study tax avoidance and admit the legality of tax avoidance, will be conducive to timely learn about the defects existing in tax law, and to further perfect the tax system on the basis of managing the tax by law, rather than to narrow the influence of tax avoidance using the power beyond law. In this way, it will not only be beneficial to the strengthening of tax legal system construction, and to the efficiency improvement of tax law enforcement.

\section{REFERENCES}

[1] Bao Chunyu. Discussion on Tax Avoidance of Foreign Invested Enterprises 2007.

[2] Fu Qiao. Discussion on Tax Planning in Market Economy.

[3] Qiu Fei. Regulations on Further Implementation and Improvement of Small and Medium-sized Enterprise Taxation Policy. Scientific Development 2012.

[4] Zhu Jianying. Study on Business Operation of Commodity Circulation and Taxation Strategy. Theses and Dissertations 2010.

[5] Zhang Gui. Analysis on Tax Avoidance Concept. Journal of Inner Mongolia Finance and Economics College 2008. 